\title{
一番茶芽生長の時系列平均
}

\author{
野菜・茶業試験場 $*$ \\ 水野直美 \\ (平成11年11月 8 日受理)
}

\section{A Time Series Averaging Method for Description of the First Tea Crop}

\author{
Naomi MIZUNO \\ National Research Institute of Vegetables, Ornamental Plants, and Tea
}

Summary

We proposed a new method to average time serieses, and analyse growth index of the first tea crop (rate of banjhi shoot, bud weight, bud length, leaf number). ${ }^{1)}$ Traditional averaging, which is adopted in annual crop report, is a simple successive averaging of numbers of data at the same calendar day. A new method proposed here is done as follows. Data of an index of each year was fitted to a logistic curve. Time value of all the inflections of an index were averaged, and phase of all curve was shifted to the averaged inflection value. Function value from daily calculation of each curves was fitted again to a logistic curve with weighing by data number. We can use the resulted curves for prediction of growth and estimation of a growth index from another.

\section{1 緒譶}

インターネット上で公開されている気象観 測システムやアメダスのリアルタイムデータ は農業上の各種予察, 警報, シミュレーショ ン，作業ガイドなどにきわめて有効であると 考えられる。一番茶の摘採適期についても， 基本的には個々の農家が直場をきちんと観察 していれば起き得ないはずの事態が最近全国 的で一斉に起きている。たとえぱ，1998年の 遅すぎた摘採による品質低下，1999年の早過 ぎる摘採による減収などがあり，農家，流通
関係者がそれぞれ対策に苦慮している。この 様な事態は, 信頼の置ける作業ガイドにより 防ぎうるもので，その実用化が期待されてい る。

国公立の茶業試験研究機関では従来より, それぞれの場所の作況園におけるデータを， 作況報告という形で公表してきた。長期間に わたる貴重なデータであるのでこれを利用し た作業ガイドを作成しようとしたが茶芽の生 長プロセスについての定式化された知見が十 分でなく利用困難であった。そこで，まず一 番茶の生長プロセスについてとりあえず過去

* T428-8501静岡県榛原郡金谷町金谷2769 
のデータに基づき現時点で最も確からしい平 均的時系列モデルを作成しようとした。しか しながら，従来作況報告で用いられている時 系列の平均值としては, 図 1 の $\mathrm{A}$ と $\mathrm{B}$ 平均 する場合に，ある時点での $\mathrm{A} と \mathrm{~B}$ を単純に平 均して描いたCに相当するものが採用されて きた。実際にはこの様な生長を示す年は存在 せず，予測などへの利用は困難である。ここ では， $\mathrm{A} ， \mathrm{~B}$ 時系列の平均は Dであると定義 し, かつ複数の生長指標間の相互参照を可能 とするために，このような時系列平均を得る 方法を開発することを目標とした。

\section{2 材料及び方法}

作況報告のデータは, 摘採日, 生葉収量, 百芽重, 芽数, 出開度からなっている。作業 ガイドは気象条件から, 現時点のこれらの数 值を予測を行うものとするため特に萌芽後の 温度に影響されやすい百芽重, 出開度に加え, 芽長, 葉数についてのモデルを作成するのが 重要である。しかしながら，これまで公表さ れている研究では参考に出来る解析例は存在

していなかった。

原田ら 夕記録した。そのうち今回は, ‘やぶきた’一番 茶の出開度, 平均全芽葉数 (以下, 葉数), 全 芽芽長 (以下, 芽長), 全芽一芽重 (以下, 芽重) を対象とし,これらの時系列的な平均生長モ デルを得ようとした。

植物の生長をあらわす場合にロジスティッ ク曲線はよく使われるが, 通常の表現形

$$
y=\frac{X}{1+k e^{-\lambda x}}
$$

又はその微分方程式

$$
\frac{d x}{d y}=\lambda y(X-y)
$$

では何れもパラメータの栽培学上の意味が不 明である。そもそも入は生育初期の指数関数 的な生長 $\left(y=e^{\lambda x}\right)$ を近似するパラメータで あり, $k$ は積分定数で $x=0$ における残され た生長余地を示す指標である。これらは何れ も理論的ないし仮想的パラメータで, 実際の 現象レベルに直接現れるものではない。その

他この表現形には，種々の問題点があったた め,

$$
y=\frac{K}{1+\mathrm{e}^{\frac{4 \rho(\tau-t)}{K}}}
$$

という形2)で利用することとした。これは口 ジスティック曲線の変曲点 $(y=K / 2)$ に於 ける微係数 $\rho$ おびその出現時間 $\tau$ をパラ メータとした表現形である。yは何らかの生 長指標であり，Kはその上限である。 $t$ は時 間であるが，この場合，4月の日付とした。 従ってたとえば $t=0$ は3/31であり， $t=10$ は $4 / 10, t=40$ は $5 / 10$ となる。図 $1 \mathrm{D}$ のう な平均を求めるには, 複数の生長曲線の $\tau$ の 平均を求め, その值に生長曲線群の位相を合 わせた上で第 1 図Cを求めたのと同様に平均 化すればよい。

カーブフィッティングと図示には主として $\mathrm{GP}^{3) を}$ 利用した。解の安定のために， $t=-$ 30 以下に生長指数 $=0$ というデータを実デー 夕の個数を超えない範囲で適宜追加した。観 測值時系列の最後の值に対するカーブフィッ ティングの際の標準偏差の百分率を $C V^{*}$ と した。ウェイトをかけたカーブフィッティン グにはNOLLS14)用いた。その他にREALbasicによる自作プログラムやMS-EXCEL 等を利用した。

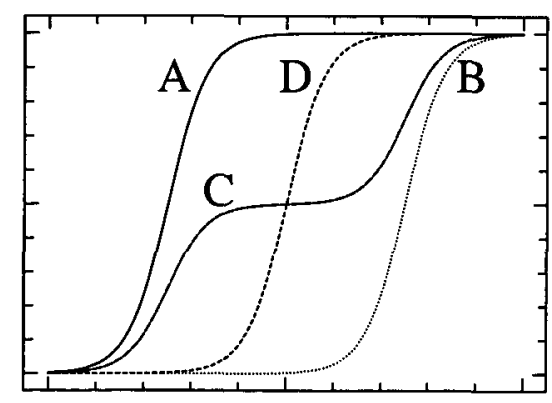

园 1 時系列における平均

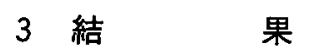

出開度, 芽重, 芽長, 葉数について順次検 討する。

\section{1 出開度}

出開度の計算結果は表 1 のようになった。 パラメータの次元などは次の通りである。 
$K:$ 最終出開度 $(\%), \rho:$ 出開度進行速度の 最大値 $(\% / 日), \tau:$ 変曲点 ( 4 月の日付)。出 開度は100\%を超えることはあり得ず, 1954年 の結果は明らかに異常であるが，これは生長 過程後半のデータが無いことによる。つまり， 1954年のデータからは $K$ の值を算出するのは 不可能である。1954年の $K$ の值の推定值とし て最も確からしい情報は1956年, 1957年の $K$ 值の平均値であるので， $K=92.3$ に固定して 1954年データで再計算した。結果は, $\rho=4.4$,

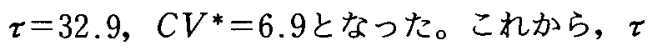
の平均值 $t$ の再マッピングを行った。つまり，1954年 は原データの日付に2.6を加え, 1956年は 2 を 減じ，1957年は0.5を減じた。パラメー夕は直 交するので表 1 の数值をこれらの值で書き換 えれば希望する結果となるが，念のため， $t$ の值を変更したデータを用いてカーブフィッ ティングを行った結果を表 2 に示す。観測 データには年次による違いがあり，1954年の データは 5 点, 1956年は同じ暦日の 5 点に加 えその後の 2 点の計 7 点, 1957年は以前とは 全く異なる 9 点の測定が行われている。結果 的に, $t=23$ から $t=25$ は1954年と1956年の データでカバーされ， $\mathrm{t}=26 \sim t=39$ には 3 年間のデータが存在し, $t=40 \sim t=47$ は 1956年と1957年の 2 年間分のデータがあり, $t=48 \sim t=58$ は1957年のみのデータがある ことになる。これらと再マッピングを考慮し て，第 2 表のカーブフィッティングで得られ た関数值からそれぞれのデータがカバーする 範囲で日毎の平均值を求めた。再マッピング 後の曲線データをLL1954の様に表すと目的 とする值は, $t=21 \sim t=25$ はLL1956, $t=$ $26 \sim t=41$ は 3 年間の平均, $t=42 \sim t=45$ はLL1956とLL1957の平均, $t=46 \sim t=57$ はLL1957のデータとなる。これらに対して， 根拠となった年数に応じて 1 から 3 のウェイ トをかけた最小二乗法で再びカーブフィッ ティングを行った。結果は $K=93.7, \rho=5.6$, $\tau=35.6$ であった。この得られた最も確から しい出開度の時系列モデルと, 根拠になった 各年の原データ及びそれぞれのカーブフィッ
ティングの結果を第 2 図に示す。これから， $6 \%$ 強の芽は最終的に出開かないこと, $t=$ 36 に出開度 $50 \%$ となること, 出開度の進行速 度は最大で一日当たり $5.6 \%$ あることがわ かる。

表 1 出開度の計算結果

\begin{tabular}{|c|c|c|c|c|}
\hline 年次 & $K$ & $\rho$ & $\tau$ & $C V^{*}$ \\
\hline 1954 & 298.7 & 8.7 & 48.4 & 6.6 \\
\hline 1956 & 92.8 & 5.7 & 37.5 & 2.2 \\
\hline 1957 & 91.8 & 6.5 & 36.0 & 2.1 \\
\hline
\end{tabular}

表 2 再マッピングデータの計算結果

\begin{tabular}{|c|c|c|c|c|}
\hline 年次 & $K$ & $\rho$ & $\tau$ & $C V^{*}$ \\
\hline 1954 & 92.3 & 4.4 & 35.5 & 6.9 \\
\hline 1956 & 92.8 & 5.7 & 35.5 & 2.2 \\
\hline 1957 & 91.8 & 6.5 & 35.5 & 2.3 \\
\hline
\end{tabular}

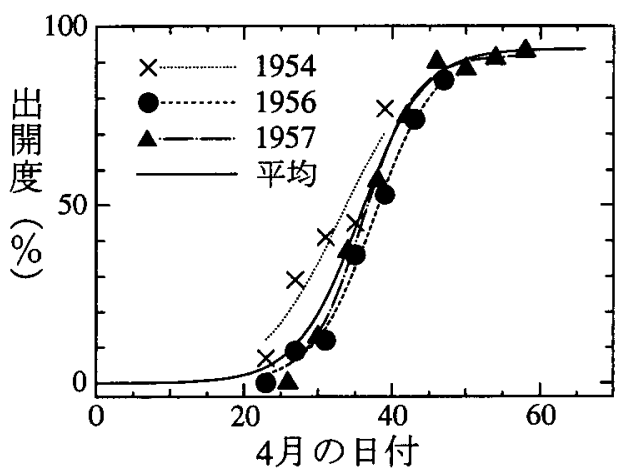

図 2 出開度時系列の平均

\section{2 芽重}

出開度と同様に(1)原データへのロジス

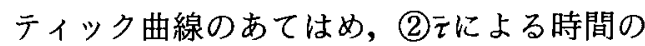
值の再マッピングとパラメータ書き換え, (3) 日毎の平均値とウエイトの算出, (4)ウェイト を考虑したロジスティック曲線のあてはめを 行い, 最も確からしい芽重の時系列モデルを 求めようとした。(1)の結果を表 3 に示す。パ ラメータの次元などは次の通りである。 $K$ : 最終芽重 $(\mathrm{mg}), \rho$ : 芽重増加速度の最大値 $(\mathrm{mg} /$ 日), $\tau$ : 変曲点 (4月の日付)。1954, 1956年のデー夕は妥当な結果であるが, 1957 年はパラメー夕が異常である。実デー夕を見 ると, 時系列の最後のデータ值が大きく, こ 
れが悪影響を及ぼしていると考えられる。最 後のデータが大きいのは，単なる確率的な変 動, 出開かない芽の生長, 重さは長さの三乗 に比例するので, 生長の後半でそもそも著し い増大が見られるものであることなどが考え られるが，このデータからだけでは判断でき ないので，とりあえず最後のデー夕を除外し， かつ変曲点を視諗できる $t=42$ に設定して計 算を行った。結果は $K=191.9, \rho=6.7, \tau=$ 42.0となったので, $\bar{\tau}=34.4$ とし(2)(3)(4)の処 理を行い図 3 を得た。最も確からしい芽重の 時系列モデルのパラメータは $K=185.3, \rho=$

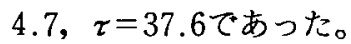

\section{表 3 芽重の計算結果}

\begin{tabular}{|c|c|r|r|r|}
\hline 年次 & \multicolumn{1}{|c|}{$K$} & \multicolumn{1}{c|}{$\rho$} & \multicolumn{1}{c|}{$\tau$} & $C V^{*}$ \\
\hline 1954 & 113.7 & 2.3 & 25.9 & 2.2 \\
\hline 1956 & 164.5 & 5.6 & 35.2 & 2.2 \\
\hline 1957 & 1688.1 & 29.7 & 84.0 & 1.7 \\
\hline
\end{tabular}

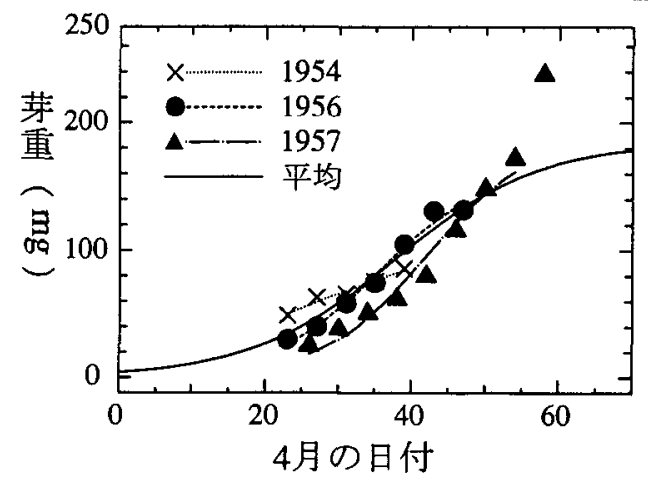

図 3 芽重時系列の平均

\section{3 . 3 芽 長}

上記と同様の処理を行おうとしたが，いず れの年もノイズのきわめて多いデータであ り、解析結果が意味を持たないと考えられた。 芽長もロジスティック的生長をするので, データは少なくとも単調増加性が強いはずで あるが，実際にはそうなっていない。実収報 告等でもこの様な例を見ることはないので， 原因はサンプリング数が過小であったことで はないかと思われるが，データ取得法につい て記載がなく，詳細は不明である。

では，この様なデータに基づく最も確から
しい芽長の時系列モデルとはどの様なものと 考えるのが適切であろうか。この実験以外の 情報を参考にしないのであれば，芽長以外の データを何らかの形で参考にする以外に解決 法はない。この観点から他のデータを見ると， 芽重の単調增加性が良好である。出開度も利 用可能であろうが，データの性質が他のもの とはかなり翼なるものであると考えられたた め，芽重を参考情報とすることにした。しか しながら，芽重は体積に関連する量であり， 芽長は長さの次元を持つ。従って, 芽重の三 乗根を求め, 芽長との比の平均值を芽重から 見た芽長の推定值と考えた。しかしながら， この推定值には芽重に含まれるノイズ成分以 外に，推定法に基づく系統譟差が含まれてい る可能性がある。問題にした芽長データには ノイズが多いが，真の情報も当然含まれてい ると考えられるので, 推定值と原データの平 均値を解析用データとした。計算過程を表 4 に示す。まず芽重 $[b]$ の三乗根を求め $[c]$, 芽長 $[a]$ との比 $[d]$ の平均值 $[e]$ を求めた。 比 $[d]$ の值には，明瞭な系統譟差はないと考 えられた。平均值 $[e]$ は Iであったので，芽 長の推定值は三乗根 $[c]$ をそのまま用い，こ れと原データ $[a]$ の平均値を解析用デー夕 $[f]$ とした。念のため求めた原データと解析 用データの差 $[g]$ にも系統誤差は存在しない と考えられた。

このデータを用い, (1)(2)(3)(4)を行扝うとし た。前項と同じ理由で1957年の最後のデータ は計算対象としなかった。(1)の結果を表 5 に 示す。パラメータの次元などは次の通りであ る。 $K$ : 最終芽長 $(\mathrm{cm}), \rho$ : 芽長増加速度の 最大值 $(\mathrm{cm} /$ 日), $\tau:$ 変曲点 ( 4 月の日付)。こ れから $\bar{\tau}=26.4$ となり, 従前通りの処理の結 果, 最も確からしい芽長の時系列モデルのパ ラメータは $K=5.1, \rho=0.1, \tau=17.1$ であっ た。結果を図 4 に示す。デー夕点は原デー夕 とし，各年の生長曲線は表 4 の補正に基づく 表 5 の結果を使ったものを示した。 
(茶研報89：1～8, 2000)

表 4 芽長の解析用データの準備

\begin{tabular}{|c|c|c|c|c|c|c|}
\hline 年. $t$ & 茅長 $[a]$ & 芽重 $[b]$ & $\sqrt[3]{b}[c]$ & $\frac{a}{c}[d]$ & $\frac{a+c}{2}[f]$ & $a-f[g]$ \\
\hline 1954.23 & 4.2 & 49 & 3.66 & 1.15 & 3.93 & 0.27 \\
\hline 27 & 3.9 & 63 & 3.98 & 0.98 & 3.94 & -0.04 \\
\hline 31 & 4.9 & 66 & 4.04 & 1.21 & 4.47 & 0.43 \\
\hline 35 & 4.2 & 76 & 4.24 & 0.99 & 4.22 & -0.02 \\
\hline 39 & 5.9 & 86 & 4.41 & 1.34 & 5.16 & 0.74 \\
\hline 1956.23 & 2.0 & 30 & 3.11 & 0.64 & 2.55 & -0.55 \\
\hline 27 & 3.1 & 40 & 3.42 & 0.91 & 3.26 & -0.16 \\
\hline 31 & 4.0 & 59 & 3.89 & 1.03 & 3.95 & 0.05 \\
\hline 35 & 5.0 & 75 & 4.22 & 1.19 & 4.61 & 0.39 \\
\hline 39 & 5.4 & 105 & 4.72 & 1.14 & 5.06 & 0.34 \\
\hline 43 & 6.0 & 131 & 5.08 & 1.18 & 5.54 & 0.46 \\
\hline 47 & 5.8 & 132 & 5.09 & 1.14 & 5.45 & 0.35 \\
\hline 1957.26 & 2.1 & 25 & 2.92 & 0.72 & 2.51 & -0.41 \\
\hline 30 & 2.7 & 38 & 3.36 & 0.80 & 3.03 & -0.33 \\
\hline 34 & 3.6 & 51 & 3.71 & 0.97 & 3.65 & -0.05 \\
\hline 38 & 3.6 & 62 & 3.96 & 0.91 & 3.78 & -0.18 \\
\hline 42 & 3.6 & 80 & 4.31 & 0.84 & 3.95 & -0.35 \\
\hline 46 & 4.1 & 116 & 4.88 & 0.84 & 4.49 & -0.39 \\
\hline 50 & 5.2 & 148 & 5.29 & 0.98 & 5.24 & -0.04 \\
\hline 54 & 5.7 & 172 & 5.56 & 1.02 & 5.63 & 0.07 \\
\hline 58 & 5.9 & 238 & 6.20 & 0.95 & 6.05 & -0.15 \\
\hline 平均 & - & - & - & $1.00[e]$ & - & 0.02 \\
\hline $\mathrm{SD}$ & - & - & - & 0.17 & - & 0.34 \\
\hline
\end{tabular}

表 5 苸長の計算結果

\begin{tabular}{|c|c|c|c|c|}
\hline 年次 & $K$ & $\rho$ & $\tau$ & $C V^{*}$ \\
\hline 1954 & 5.5 & 0.1 & 14.2 & 3.8 \\
\hline 1956 & 5.9 & 0.2 & 25.1 & 1.5 \\
\hline 1957 & 8.0 & 0.1 & 39.8 & 2.5 \\
\hline
\end{tabular}

\section{4 葉 数}

葉数も芽長と同じくノイズの多いデータで あったので，同様に前処理を行い解析用デー 夕を得た。処理過程を表 6 に示す。芽長と同 しく, 芽重 $[b]$

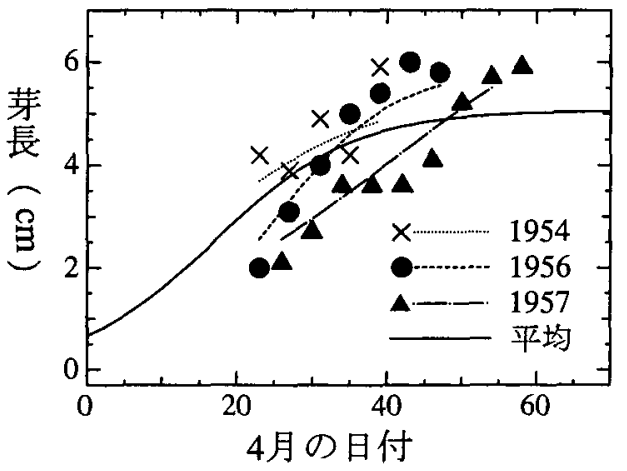

図 4 芽長時系列の平均

比 $[d]$ の平均值 $[e]$ を求めたところ，0.73で あったので，三乗根 $[c]$ と平均值 $[e]$ の積を 葉数の推定值 $[f]$ とし，これと原データ $[a]$ の平均値を解析用データ $[g]$ とした。比 $[d]$

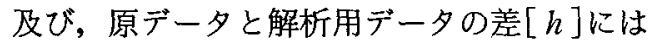


系統誤差は存在しないと考えられた。

このデータを用い前項と同じ処理を行っ た。(1)の結果を表 7 に示す。パラメータの次 元などは次の通りである。 $K$ : 最終葉数(枚), $\rho$ : 葉数増加速度の最大值 $($ 枚 $/$ 日 $), \tau$ : 変曲
点( 4 月の日付)。 $\tilde{\tau}=21.1 て ゙ あ り$, 最も確から しい葉数の時系列モデルのパラメータは $K=$ $3.9, \rho=0.1, \tau=19.6$ であった(図 5 )。

3. 5 生長指標間の相互推定

各生長指標の平均的モデルが求まったこと

表 6 葉数の解析用データの準備

\begin{tabular}{|r|r|r|r|r|r|r|r|}
\hline \multicolumn{1}{|c|}{ 年. $t$} & 葉数 $[a]$ & 芽重 $[b]$ & $\sqrt[3]{b}[c]$ & $\frac{a}{c}[d]$ & $c \times e[f]$ & $\frac{a+f}{2}[g]$ & $a-f[g]$ \\
\hline 1954.23 & 2.6 & 49 & 3.66 & 0.71 & 2.67 & 2.63 & -0.03 \\
\hline 27 & 3.1 & 63 & 3.98 & 0.78 & 2.90 & 3.00 & 0.10 \\
\hline 31 & 3.2 & 66 & 4.04 & 0.79 & 2.95 & 3.07 & 0.13 \\
\hline 35 & 3.4 & 76 & 4.24 & 0.80 & 3.09 & 3.24 & 0.16 \\
\hline 39 & 3.2 & 86 & 4.41 & 0.72 & 3.22 & 3.21 & -0.01 \\
\hline 1956.23 & 2.5 & 30 & 3.11 & 0.80 & 2.27 & 2.38 & 0.12 \\
\hline 27 & 2.5 & 40 & 3.42 & 0.73 & 2.49 & 2.50 & 0.00 \\
\hline 31 & 2.8 & 59 & 3.89 & 0.72 & 2.84 & 2.82 & -0.02 \\
\hline 35 & 3.1 & 75 & 4.22 & 0.74 & 3.08 & 3.09 & 0.01 \\
\hline 39 & 3.3 & 105 & 4.72 & 0.70 & 3.44 & 3.37 & -0.07 \\
\hline 43 & 3.6 & 131 & 5.08 & 0.71 & 3.70 & 3.65 & -0.05 \\
\hline 47 & 3.7 & 132 & 5.09 & 0.73 & 3.71 & 3.71 & -0.01 \\
\hline 1957.26 & 2.3 & 25 & 2.92 & 0.79 & 2.13 & 2.22 & 0.08 \\
\hline 30 & 2.6 & 38 & 3.36 & 0.77 & 2.45 & 2.53 & 0.07 \\
\hline 34 & 2.8 & 51 & 3.71 & 0.76 & 2.71 & 2.75 & 0.05 \\
\hline 38 & 3.0 & 62 & 3.96 & 0.76 & 2.89 & 2.94 & 0.06 \\
\hline 42 & 3.2 & 80 & 4.31 & 0.74 & 3.14 & 3.17 & 0.03 \\
\hline 46 & 3.3 & 116 & 4.88 & 0.68 & 3.56 & 3.43 & -0.13 \\
\hline 50 & 3.6 & 148 & 5.29 & 0.68 & 3.86 & 3.73 & -0.13 \\
\hline 54 & 3.6 & 172 & 5.56 & 0.65 & 4.06 & 3.83 & -0.23 \\
\hline 58 & 3.5 & 238 & 6.20 & 0.56 & 4.52 & 4.01 & -0.51 \\
\hline 平均 & - & - & - & $0.73[e]$ & - & - & -0.02 \\
\hline $\mathrm{SD}$ & - & - & - & 0.06 & - & - & 0.15 \\
\hline
\end{tabular}

表 7 葉数の計算結果

\begin{tabular}{|l|l|l|l|l|}
\hline 年次 & \multicolumn{1}{|c|}{$K$} & $\rho$ & $\tau$ & $C V^{*}$ \\
\hline 1954 & 3.2 & 0.2 & 15.7 & 1.3 \\
\hline 1956 & 4.2 & 0.1 & 21.7 & 1.9 \\
\hline 1957 & 4.3 & 0.1 & 25.9 & 1.5 \\
\hline
\end{tabular}

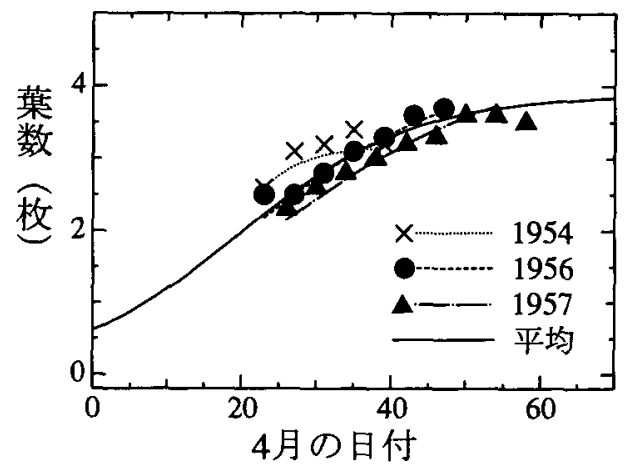

図 5 葉数時系列の平均 
により，これを利用して，ある時点 $[t]$ あ る生長指標 $[K]$ から生長曲線の時間軸の位置 $[\hat{t}]$ を割り出せる。 $[\hat{t}]$ は $[t]$ とは異なり, 生物 学的時間ないし, 仮想時間といったもので, 気候や植物体の状態の平均的な性質を表すも のである。更にこれを用いて他の生長指標の 值を求めることも可能である。ある生長指標 $[y]$ から,生物学的時間 $[\hat{t}]$ を算出するには,

$$
\hat{t}=\tau-\frac{K \ln \left(\frac{K}{y}-1\right)}{4 \rho}
$$

を計算すればよい。得られた $\hat{t}$ を他の生長指標 の計算式に代入すれば，その時点での值が求 まる。計算用に有効数字の多いパラメー夕值
を表 8 に揭げる。また，各生長指標がどの様 な関連をもって時間的発達を示すかを見るた めに，それぞれの最大值でスケーリングした ものを図 6 に示す。

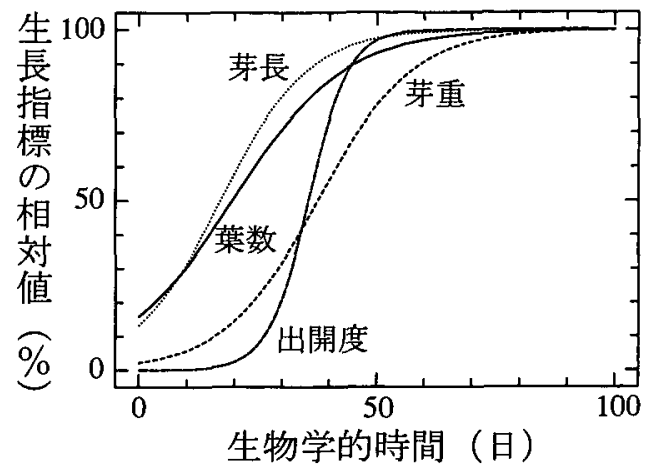

図 6 生長指標の相対变化

表 8 各生長指標の平均モテル

\begin{tabular}{|c|c|c|c|}
\hline 指標 & $K$ & $\rho$ & $\tau$ \\
\hline 出開度 & $9.3684860 \mathrm{E}+01$ & $5.5585217 \mathrm{E}+00$ & $3.5620907 \mathrm{E}+01$ \\
\hline 芽 重 & $1.8532297 \mathrm{E}+02$ & $4.6878724 \mathrm{E}+00$ & $3.7575554 \mathrm{E}+01$ \\
\hline 芽 医 & $5.0626278 \mathrm{E}+00$ & $1.3887674 \mathrm{E}-01$ & $1.7082516 \mathrm{E}+01$ \\
\hline 葉 数 & $3.8924036 \mathrm{E}+00$ & $8.2601801 \mathrm{E}-02$ & $1.9562601 \mathrm{E}+01$ \\
\hline
\end{tabular}

4

察

図 1 の, $\mathrm{A}, \mathrm{B}$ 時系列において, 従来広く 行われてきたCを平均とする方法は，予測な どに利用困難である。今回, 平均値として D を考える方法論を確立することが出来た。出 開度, 芽重, 芽長, 葉数の時系列平均が求まっ たので，これを用いた予測が可能となった。 つまり，ある指標のある時点における值から， 生物学的時間 $\hat{t}$ 求め, これに任意の日数を足 して指標の值を計算すれば，それがその日の 予測值となる。また, ある指標から, 他の指 標を推定するのは, 同様に得られた $\hat{t}$ 他の指 標のモデル式に代入することにより達成でき る。

生長指標の時間的進行は, 萌芽直後は葉数 が先行し，ついで芽長が追随して追い越し， その後芽重が増加するというパターンであ る。出開度は, 生長後期に立ち上がり, 短時 間に他の指標を相対値として追い越す。これ らの知見は, 従来経験的に観察されてきたこ
とと合致するが，精度の高い内挿部分だけで なく，精度の保証がない外扦部分についての 議論も入っているので注意が必要である。こ れは，今後データ例が増えることにより解消 されるであるう。

本解析は, 一番茶芽生長について行われた が, 一番茶芽の一部, 特に頂芽は長く伸長を 続け, 出開かない特徴を持つ1)。このためデー 夕取得は, 枠摘みで全芽摘採を行い, サイズ 別にデータを取得する必要があると考えられ た。

今後は，他のデータも最大限取り込み，「実 測值を保持するモデル」の形でより信頼度の 高いものに発展させたい。但し，実際の圃場 の現象に「平均値」は出現しないことはいう までもない。一番茶生長全体に対して，大き な影響を与えるものとして，たとえば栄養状 態があろうし，短時間的に強い影響を与える 要因として，気温があげられる。精度の高い 平均值を基準とすれば，そこからの乘離を気 温など他の要因と関連づけることが容易とな 
り：シミュレータ5)の精度をより高めること が出来る。現在のシミュレータの改善と, 作 況報告の情報の利用により，農家の指針とな るような作業ガイドを作成していきたいと考 える。

$$
5 \text { 摘 要 }
$$

時系列の平均を求める新たな方法を提案 し, 一番茶芽の生長データ（出開度, 芽重, 芽長, 葉数) のプロセス解析を行った。従来 作況報告などに見られる時系列の平均は, 単 純にある暦日の複数のデータの平均值を順次 計算したものであった。今回提案の方法では, ロジスティック曲線に適合するデータ群を変 曲点の時間軸の值の平均值に位相合わせを行 い，更にデータ点数による重みづけをした最 小二乗法で全体の系列を平均化しようとする ものである。この手法によって求められた平 均時系列により, 実際の生長の予測や, 異な る指標間の推定が可能となった。

\section{6 引用文 献}

1) 原田重雄・増田清志・安間舜（1960）：茶 葉の熟度に関する研究（第 1 報）一手摘 緑茶の部一茶芽の摘採期と生育・収量と の関係。東海近畿農業試験場研究報告茶 業部, 7, 91-109.

2 ）水野直美・加古舜治・榊原孝平 (1979): パフィオペディルムの開花調節 (第 3 報) 冬咲性品種の発育・開花特性. 園芸学会 昭和 54 年度春季大会研究発表要旨, 318-319.

3 ）枝松圭一 (1997): GP version 4.20. http://laser.mp.es.osaka-u.ac.jp/gp/

4) Tanabe, K., and S. Ueda. 1981. NOLLS1 VERSION OF MARCH 19, 1981.

http://www.ism.ac.jp/software/products.html

5 ）水野直美 (1999)：温度応答特性に基づく ‘やぶきた’の新梢成長のシミュレーショ ン, 茶業研究報告, 88(別冊), 96-97. 